\title{
FACTORS THAT INFLUENCE STUDENTS IN CHOOSING PRIVATE UNIVERSITIES IN INDONESIA
}

\author{
Artyasto Jatisidi ${ }^{1}$ and Nawiroh Vera ${ }^{2}$ \\ ${ }^{1}$ Communication Department, Universitas Budi Luhur Jakarta-Indonesia \\ Email: nawiroh.vera@budiluhur.ac.id \\ ${ }^{2}$ Communication Department, Universitas Budi Luhur Jakarta-Indonesia. \\ E-mail: artyasto.jatisidi@budiluhur.ac.id
}

Cite this article:

Artyasto J., Nawiroh V. (2021), Factors that Influence Students in Choosing Private Universities in Indonesia.

British Journal of

Contemporary Education 1(1), 99-108. DOI: 10.52589/BJCEDWDEUWQG.

\section{Manuscript History}

Received: 12 Nov 2021

Accepted: 1 Dec 2021

Published: 14 Dec 2021

Copyright $\odot 2020$ The Author(s). This is an Open Access article distributed under the terms of Creative Commons AttributionNonCommercial-NoDerivatives 4.0 International (CC BY-NC-ND 4.0 ), which permits anyone to share, use, reproduce and redistribute in any medium, provided the original author and source are credited.
ABSTRACT: This research is based on questions about what factors are considered by high school students in choosing a private university in Indonesia. This research is a quantitative study using survey methods. Information is extracted and presented by the Factor Analysis method. The stages in this research begin with the study of literature, determining variables and indicators. Field data collected through the distribution of questionnaires are presented in accordance with available facts, organized and systematic. After analysis and discussion, based on factor analysis through statistical tests, there are several factors that are considered by high school students in selecting private universities, namely academic, promotion, registration process, lecture process, tuition fees, campus location, and lecturer reputation. Based on the statistical analysis of factor analysis as a measurement, it can be seen that the first factor that most dominantly influences students' decisions in choosing a private university is the promotion factor, especially through the university's website. The complete private university website contains information about study programs (curriculum, activities, etc.), besides that, the website has an attractive appearance and is easily accessible to be the first target in finding information about the college.

KEYWORDS: Factor Analysis, Survey Methods, Quantitative 


\section{INTRODUCTION}

Education is a major need in increasing Indonesia's human resources. Higher education is very important because graduates from tertiary institutions are expected to produce quality human resources and have high competitiveness. the fact is that one's education influences that person's work. High School students' priorities in choosing tertiary institutions are State universities. Because state universities are more prestigious, tuition fees are cheaper than in private universities, there are also many study programs offered at state universities, whereas private universities have a more limited choice of study programs.

Choosing a university needs certain considerations, choosing a university is also influenced by several factors. The main factor influencing a person in choosing a university comes from himself or comes from the surrounding environment [1]. Each private university implements a different strategy in promoting their campus, according to marketing theory the university must know information about the needs and desires of consumers, in this case, prospective students and parents who become their consumers.

This research was conducted with the aim of providing input for universities in DKI and Banten, especially in developing appropriate strategies in reaching the number of new students. What factors are considered by prospective students in choosing a private tertiary institution to be important in marketing the study programs contained in the university? Prospective students are the target market for earning income.

Based on the phenomena that have been described, the research is interested in conducting research on what factors are considered by high school students in selecting private universities. The study was conducted using multivariate analysis, namely the Structural Equation Modeling Method. The research subjects were high school students who currently sit in class XII who are studying in Jakarta, Tangerang. Indonesia.

The purpose of this study was to determine what factors influenced high school students and their equivalents in South Jakarta and Tangerang in choosing a private university.

\section{Theoretical framework}

\section{Marketing}

According to Philip Kotler, marketing is "social and managerial processes carried out by a person or group to obtain what they need and want through the creation and exchange of products and values" [2]. According to Stanton, the definition of marketing is "an overall system of business activities aimed at planning, pricing, promoting and distributing goods or services that satisfy the needs of both existing and potential buyers". Sofyan Assauri, the notion of marketing is an effort to provide and deliver the right goods and services at the right place and time and at the right price with the right promotion and communication [3].

From the definitions of marketing, it can be said that marketing is a major activity that should be carried out by a company both goods and service companies so that the company maintains its existence, therefore it can be said that the principle of marketing is to combine communication and promotion. 


\section{Marketing Mix}

The marketing mix is at the centre of the strategic marketing process. This is the mechanism used to carry out the strategic plan. Kotler provides a definition of the marketing mix as marketing tools used to pursue marketing objectives in a targeted market [4].

The basis of the marketing mix is the $4 \mathrm{P}$ structure that was first introduced by Mc Carthy in 1970. He identified elements that could be influenced and manipulated in how to market a product and provided a framework for analyzing each element: product, price, promotion (promotion), place/distribution (place) systematically.

The mixture is how these elements are combined to create an action plan that is appropriate for the customer in the targeted market. The current marketing mix continues to grow according to the circumstances, the development of the marketing mix is applied primarily in the service sector. In addition to the special $4 \mathrm{P}$ in the service sector plus $3 \mathrm{P}$, namely people, process, physical evidence, known as the 7P service marketing mix.

In research on the considerations of someone in choosing further study to tertiary institution, it is considered appropriate to use 7P marketing mix theory, this is because tertiary institutions as educational institutions are engaged in services, namely education services. The concepts of the $7 \mathrm{P}$ theory are adapted to the conditions of each implementing institution, the $7 \mathrm{P}$ concept can be used to make decisions in making marketing strategies.

The seven elements of the marketing mix are explained as follows:

1. Product (product or service); everything that can be offered to the market in order to get attention, be bought, used, consumed and can satisfy the wants or needs of the market [5]. In the field of product, service is defined as something that can provide benefits and can meet consumer needs. In colleges/universities, the products are science and education

2. Price (price); price is an economic sacrifice made by the customer in order to obtain certain products or services [6].In higher education institutions the price is an element that runs parallel to the quality of the product, where if the product is of good quality, students or students dare to pay higher insofar as they are within the reach of education customer affordability [7].

3. Promotion (promotion); is a form of marketing communication, namely marketing activities that seek to disseminate information, influence, persuade, and/or remind target markets for institutions and products to be willing to accept, buy, and be loyal to the products offered by these institutions [8].

4. Place (place/location); location or location where the institution or company distributes its products/services to consumers. In this study is the location of the campus/university.

5. People (Human Resources); People are the main assets in the service industry, especially businesses that require high-performance resources. Consumer needs for high-performing employees will cause consumers to be satisfied and loyal. The ability of knowledge (knowledge) is good, will become a basic competency in the 
company's internal and good imaging outside. (Https://karinov.co.id/peng understanding-bauran-market-7p/) [9].

6. Process: Service or product quality is very dependent on the process of delivering services to consumers. Considering that the service company mover is the employee itself, to ensure the quality of service (quality assurance), all company operations must be carried out in accordance with standardized systems and procedures by employees who are competent, committed and loyal to the company where they work.

7. Physical Evidence (Corporate Physical Evidence); Building is a part of physical evidence, a characteristic that becomes a value-added requirement for consumers in service companies that have character. Attention to interiors, building equipment, including lighting systems, and roomy layout is an important concern and can affect the mood of visitors.

\section{Model of Marketing Mix in Choosing Colleges}

The marketing mix model in selecting research universities is based on similar research studies that have been carried out and published which are a literature review of this research. This model was made using a factor analysis explanation from existing research with the consideration that the indicators are still in the form of assumptions (untested truth).

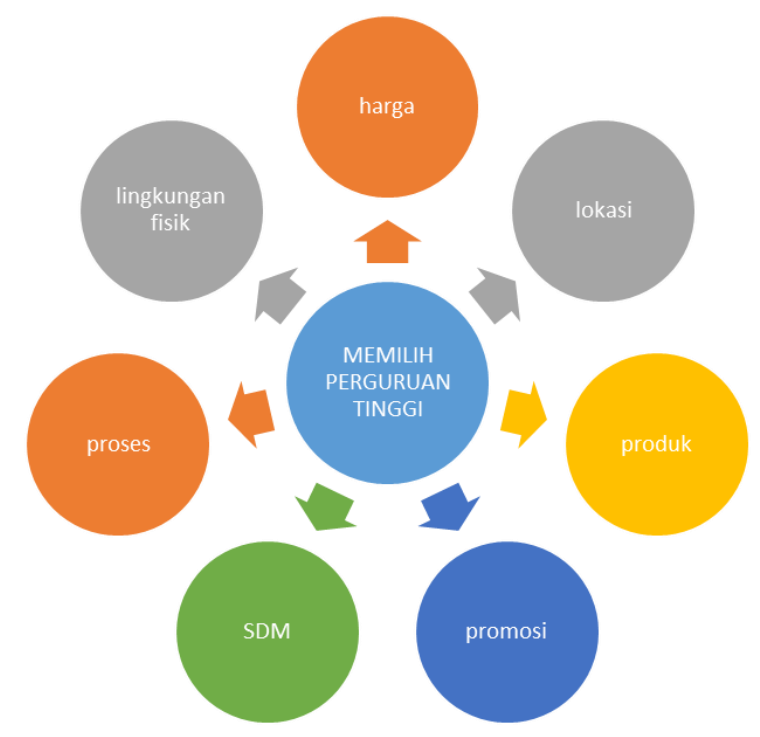

Figure 1: Model of Marketing Mix in Choosing Colleges 


\section{Research Methods}

This research is quantitative research. The research instrument used in this study was a list of questions or also referred to as a questionnaire. The questionnaire in this study was designed to refer to the indicators contained in the theories and concepts that researchers used. The theory of substance used is the marketing mix theory of Philip Kotler relating to the formulation of the problem and the purpose of this study.

\section{RESULTS AND DISCUSSIONS}

The results of the study are the results of data processing and analysis. Data analysis was conducted to find out what factors were considered by high school students and their equivalents in determining or choosing a private tertiary institution to continue their education. The first step in analyzing the data in this study is to conduct a descriptive statistical analysis to determine the respondents' exact and clear background. Furthermore, after the respondent's background is known, the researcher analyzes the factors that influence students in choosing tertiary institutions to continue their education.

\section{Assumptions of factor analysis that must be met are:}

1. Correlation between independent variables. The amount of correlation or correlation between independent variables must be strong enough, for example, above 0.5 .

2. Partial Correlation. Large partial correlation, the correlation between two variables by assuming the other variables are fixed, must be small. In SPSS detection of partial correlation is given via the Anti-Image Correlation option.

3. Testing the entire correlation matrix (correlation between variables), measured by the magnitude of the Bartlett Test of Sphericity or Measuring Sampling Adequacy (MSA). This test requires a significant correlation between at least several variables.

4. In some cases, the assumption of normality of the variables or factors that occur should be fulfilled.

Results from Factor Analysis

Data that has been successfully collected for subsequent analysis uses factor analysis using the SPSS 23. Factor analysis is data analysis to find out the dominant factors in explaining a problem. The basic concept of factor analysis is as follows:

1. Bartlett's Test of Sphericity; to find out if there is a significant correlation between variables

2. Correlation Matrix; This matrix shows the relationship between variables. A high or significant correlation value indicates that the two variables are closely related. (Minimum 0.3, at the 95\% significant level).

3. Communality; the magnitude of the variable variance filtered with other variables. 
4. Eigen Value; the total variance that can be explained by each factor.

5. Scree plot; the plot of the eigenvalue as a vertical axis and the number of factors as a flat axis, to determine the number of factors that can be drawn (factor extraction)

6. KMO measure of sampling adequacy; index used to test the suitability of factor analysis, the value of at least 0,5 [10].

\section{Determinant of Correlation Matrix Test}

Assumptions for the first-factor analysis are Determinants of Correlation Matrix Test. The correlation matrix is said between interrelated variables if the determinant value is close to 0 . The calculation results show the determinant of correlation matrix value of $4.424 \mathrm{E}-11$ or 4.424 $\mathrm{x} 10-11$ that is 0.00000000004424 . This value approaches 0 , thus the correlation matrix between the variables is interrelated.

\section{Kaiser Meyer Olkin Measure of Sampling and Bartlett Test of Sphericity}

Assumption Analysis for the second factor- Kaiser Meyer Olkin Measure of Sampling (KMO) is an index of the distance comparison between the correlation coefficient with its partial correlation coefficient. If the sum of the squares of partial correlation coefficients among all pairs of variables is small compared to the sum of the squares of the correlation coefficient, it will produce a KMO value close to 1 . The KMO value is considered sufficient if more than 0.5 . The results of KMO in this study are shown in the table below:

\section{Table 1: KMO and Bartlett's Test}

\begin{tabular}{|lr|r|}
\hline $\begin{array}{l}\text { Kaiser-Meyer-Olkin Measure of Sampling } \\
\text { Adequacy. }\end{array}$ & .871 \\
$\begin{array}{l}\text { Bartlett's Test of } \\
\text { Sphericity }\end{array}$ & Approx. Chi-Square & 3373.556 \\
& & 703 \\
& df & 0.000 \\
\hline
\end{tabular}

The results showed that the value of the Kaiser Meyer Olkin Measure of sampling was 0.871 . Because the value 0.871 is greater than 0,5 the KMO requirements thus meet the requirements because it has a value above 0,5 . This shows the adequacy of the sample. Then it can be concluded that the factor analysis test can be continued. The results of calculations with SPSS generated a Barlett Test of Sphericity value of 3373,556 with a significance of 0,000. Thus the Bartlett Test of Sphericity meets the requirements because the significance is below $0.05(5 \%)$. This shows that there is a correlation between variables and is feasible for further processing. 
British Journal of Contemporary Education

Volume 1, Issue 1, 2021 (pp. 99-15)

www.abjournals.org

\section{Community}

Results of the test of communality are as follows:

Tabel 2

\begin{tabular}{|c|c|c|}
\hline & Initial & Extraction \\
\hline P1 & 1.000 & .726 \\
\hline$\overline{\mathrm{P} 2}$ & 1.000 & .697 \\
\hline$\overline{\mathrm{P} 3}$ & 1.000 & .700 \\
\hline P4 & 1.000 & .629 \\
\hline P5 & 1.000 & .616 \\
\hline $\mathrm{P} 6$ & 1.000 & .701 \\
\hline P7 & 1.000 & .654 \\
\hline P8 & 1.000 & .642 \\
\hline P9 & 1.000 & .614 \\
\hline P10 & 1.000 & .519 \\
\hline P11 & 1.000 & .674 \\
\hline P12 & 1.000 & .701 \\
\hline P13 & 1.000 & .627 \\
\hline P14 & 1.000 & .697 \\
\hline P15 & 1.000 & .634 \\
\hline P16 & 1.000 & .496 \\
\hline $\mathrm{P} 17$ & 1.000 & .606 \\
\hline $\mathrm{P} 18$ & 1.000 & .740 \\
\hline P19 & 1.000 & .582 \\
\hline $\mathrm{P} 20$ & 1.000 & .649 \\
\hline P21 & 1.000 & .711 \\
\hline P22 & 1.000 & .700 \\
\hline P23 & 1.000 & .557 \\
\hline $\mathrm{P} 24$ & 1.000 & .720 \\
\hline $\mathrm{P} 25$ & 1.000 & .708 \\
\hline $\mathrm{P} 26$ & 1.000 & .652 \\
\hline $\mathrm{P} 27$ & 1.000 & .672 \\
\hline P28 & 1.000 & .673 \\
\hline P29 & 1.000 & .757 \\
\hline P30 & 1.000 & .682 \\
\hline P31 & 1.000 & .691 \\
\hline P32 & 1.000 & .804 \\
\hline P33 & 1.000 & .747 \\
\hline P34 & 1.000 & .661 \\
\hline $\mathrm{P} 35$ & 1.000 & .685 \\
\hline $\mathrm{P} 36$ & 1.000 & .705 \\
\hline P37 & 1.000 & .700 \\
\hline P38 & 1.000 & .640 \\
\hline
\end{tabular}

Extraction Method: Principal Component Analysis. 
The table above shows that the value of commonality of all variables $>0.5$, (greater than $50 \%$ ), then the assumption of commonality is fulfilled.

\section{Factor Rotation}

The result of the factor rotation is shown in the table below:

Tabel 3: Rotated Component Matrix ${ }^{a}$

\begin{tabular}{|c|c|c|c|c|c|c|c|c|c|}
\hline & \multicolumn{9}{|c|}{ Component } \\
\hline & 1 & 2 & 3 & 4 & 5 & 6 & 7 & 8 & 9 \\
\hline P24 & .776 & .181 & .157 & -.017 & .035 & .104 & .117 & .103 & .156 \\
\hline 33 & .726 & .284 & .056 & .189 & .270 & .160 & 016 & -.028 & .032 \\
\hline P25 & .707 & .196 & .267 & .101 & .012 & .001 & .162 & .248 & .011 \\
\hline P36 & .643 & .292 & .251 & .218 & .094 & .063 & .289 & .013 & .022 \\
\hline P12 & .588 & .316 & .053 & .275 & .130 & .108 & .215 & .105 & .303 \\
\hline $\mathrm{P} 23$ & .445 & .152 & .363 & .012 & .364 & .070 & .071 & .119 & -.217 \\
\hline P16 & .437 & .199 & .334 & .229 & .196 & .243 & .028 & .066 & .002 \\
\hline P17 & .431 & .140 & .421 & .208 & .392 & .102 & .029 & .124 & .010 \\
\hline P8 & .144 & .749 & .056 & .000 & .078 & .080 & .153 & .141 & .035 \\
\hline $\mathrm{P} 2$ & .273 & .680 & .097 & .327 & .045 & .107 & .072 & -.153 & -.041 \\
\hline P7 & .288 & .669 & .183 & .013 & .180 & .045 & .186 & .144 & .010 \\
\hline P1 & .345 & .632 & .181 & .358 & .052 & .029 & .054 & -.198 & -.014 \\
\hline P6 & .115 & .604 & .260 & .054 & .270 & .023 & .326 & .263 & -.059 \\
\hline P4 & .089 & .590 & .387 & .225 & .188 & $\begin{array}{r}- \\
.019\end{array}$ & .137 & .102 & .089 \\
\hline P5 & .324 & .572 & .198 & .062 & .192 & $\begin{array}{r}- \\
.016\end{array}$ & .194 & .188 & .179 \\
\hline P13 & .423 & .450 & .217 & .232 & .182 & $\begin{array}{r}- \\
.039\end{array}$ & .009 & .231 & .239 \\
\hline $\mathrm{P} 22$ & .271 & .210 & .743 & .106 & .095 & .033 & .096 & .020 & .003 \\
\hline P21 & .241 & .209 & .732 & .107 & -.081 & .057 & .104 & .105 & .175 \\
\hline P20 & .049 & .168 & .700 & -.063 & .232 & .193 & .145 & -.051 & .095 \\
\hline P15 & .409 & .142 & .426 & .047 & .002 & .250 & $\begin{array}{r}- \\
.016\end{array}$ & .346 & .284 \\
\hline P19 & .225 & .135 & .404 & -.030 & .178 & .210 & .221 & .248 & .403 \\
\hline P18 & -.101 & .221 & .262 & .684 & .225 & .033 & .266 & -.025 & .150 \\
\hline P3 & .255 & .123 & .039 & .643 & .096 & $\begin{array}{r}- \\
.070\end{array}$ & $\begin{array}{r}- \\
.084\end{array}$ & .400 & -.155 \\
\hline P11 & .357 & .086 & -.094 & .633 & .113 & .123 & .189 & .009 & .256 \\
\hline P14 & .402 & .314 & .072 & .558 & -.080 & .331 & .053 & .035 & .019 \\
\hline P31 & .145 & .293 & .123 & .036 & .705 & .236 & .032 & .038 & .109 \\
\hline
\end{tabular}




\begin{tabular}{|c|c|c|c|c|c|c|c|c|c|}
\hline P32 & .433 & .174 & .128 & .223 & .645 & .156 & .142 & -.034 & .242 \\
\hline P34 & .088 & .206 & .057 & .169 & .623 & .008 & .311 & .224 & .210 \\
\hline P29 & .094 & -.076 & .192 & -.094 & .241 & .787 & .031 & .085 & -.100 \\
\hline P28 & .232 & .076 & .018 & .206 & -.079 & .744 & .029 & -.018 & .099 \\
\hline P30 & -.099 & -.022 & .337 & -.020 & .401 & .597 & .150 & .130 & -.002 \\
\hline P27 & .028 & .163 & -.088 & .135 & .027 & .560 & $\begin{array}{r}- \\
.010\end{array}$ & .551 & .030 \\
\hline P37 & .255 & .264 & .122 & .133 & .038 & .089 & .673 & .167 & .204 \\
\hline P38 & .445 & .156 & .276 & .187 & .084 & .171 & .507 & .116 & -.009 \\
\hline & .480 & .317 & .087 & .112 & .179 & .004 & .493 & -.181 & .160 \\
\hline P26 & .158 & .108 & .144 & .055 & .137 & .106 & .140 & .730 & .095 \\
\hline & -.040 & -.111 & .127 & .052 & .122 & .124 & .180 & -.014 & .650 \\
\hline P9 & .341 & .247 & .049 & .092 & .114 & .144 & .026 & .120 & .614 \\
\hline
\end{tabular}

Extraction Method: Principal Component Analysis.

Rotation Method: Varimax with Kaiser Normalization.

a. Rotation converged in 11 iterations.

Factor variable is determined by looking at the value of the largest correlation. The table above has been sorted from the largest to the smallest values per factor.

Look carefully at the results above: P24 has the greatest correlation with a factor of 1, namely 0.776, as well as P33, P25, P36, P12, P23, P16 and P17. So that P24, P33, P25, P36, P12, P23, $\mathrm{P} 16$ and $\mathrm{P} 17$ are members of the group or factor 1 . While those most correlated with factor 2 are P8, P2, P7, P1, P6, P4, P5 and P13. And so on until a factor of 9. (The yellow colour in the table means one group).

\section{CONCLUSIONS}

Based on the results of a survey of selected respondents and the results of the factor analysis and the previous discussion the conclusions of this study are:

1. Based on the factor analysis of the research variables declared valid, thus the measuring instrument used was considered appropriate so that the results of the study could be justified in terms of ethics and academics.

2. Through the factor analysis statistical test as a measurement, it can be seen that the first factor that most dominantly influences the student's decision in choosing a private tertiary institution is the promotion factor, especially through the university's website. The complete private university website contains information about study programs (curriculum, activities, etc.). Besides that, the website has an attractive appearance and is easily accessible to be the first target in finding information about the college. 
3. The second most prominent factor is the strategic location of the campus, safe and conducive. This location is primarily a consideration of parents in determining the university to be chosen.

4. Lecturer reputation and achievement and teaching experience of lecturers are also the concern of respondents (in this case high school students) in determining the campus to be chosen.

5. No less important is the economic factor in this case the existence of various types of scholarships offered by the campus such as performance scholarships during college (ongoing scholarship). The payment process is simple and easy, for example through e-banking, and other technical facilities. Payment does not have to come to campus, it can be done anywhere.

\section{REFERENCES}

[1] Oktaviani, Yulianti. Analisis faktor-faktor yang mempengaruhi siswa memilih SMK bidang keahlian teknik bangunan sebagai sekolah lanjutannya di kabupaten Garut. 2013, http:// repistory.upi.edu

[2] Suyanto, M. Analisis \& Desain Aplikasi Multimedia untuk Pemasaran. Yogyakarta: Andi, 2004, 1.

[3] Sofyan, Assauri. Manajemen Pemasaran. Jakarta: Rajawali Pres, 2010, 2.

[4] Vellas, Francois \& Becherel, Lionel, Pemasaran Pariwisata Internasional (penerjemah: Indriati) Jakarta: Yayasan Obor Indonesia. 2008, 142

[5] Kotler, Philip. Principles of Marketing. Prentice-hall inc, New Jersey (perilaku konsumen). Jakarta: PT Indeks, 2008, 54.

[6] Monroe, KB, Pricing: Making Profitable Decisions. Edisi 3. New Delhi: MacGraw Hill, 2003, 123.

[7] Sunaengsih, Cucun, Buku Ajar Pengelolaan Pendidikan. Sumedang: UPI Sumedang Press, 2017, 94.

[8] Sunaengsih, Cucun, Buku Ajar Pengelolaan Pendidikan. Sumedang: UPI Sumedang Press, 2017, 95

[9] https://karinov.co.id/pengertian-bauran-pemasaran-7p/

[10] Source: http: //miftakhurrizal.lecture.ub.ac.id/files/2018/02/Analisis-Faktor.pdf 